\title{
Critical Operations Capabilities for Competitive Manufacturing in a High-Cost Environment: A Multiple Case Study
}

\author{
Cinzia Sansone \\ Department of Supply Chain and Operations Management, \\ School of Engineering, Jönköping University, P.O. Box 1026, SE-551 11, Jönköping, Sweden \\ E-mail: Cinzia.Sansone@ju.se \\ Per Hilletofth \\ Department of Supply Chain and Operations Management, \\ School of Engineering, Jönköping University, P.O. Box 1026, SE-551 11, Jönköping, Sweden \\ Department of Industrial Engineering and Management, \\ University of Gävle, SE-801 76, Gävle, Sweden \\ David Eriksson \\ Department of Supply Chain and Operations Management, \\ School of Engineering, Jönköping University, P.O. Box 1026, SE-551 11, Jönköping, Sweden
}

\begin{abstract}
There is increased interest in relocation to and from highcost environments, but there remains a lack of knowledge with regard to operations capabilities in this specific context. The purpose of this study is thus to investigate critical operations capabilities in a high-cost environment. The research process is based on the investigation of an existing framework of operations capabilities through a multiple case study including five Swedish manufacturing companies. The findings reveal that all the dimensions and capabilities included in the framework were considered critical, and additional operations capabilities could be identified: service quality, supplier dependability, supplier flexibility, supply chain innovation, supply chain sustainability. The investigation underlines the dynamic nature of operations capabilities, which need to be updated constantly according to the environment in which they are developed. This study contributes on a practical level to managers by creating an overview of operations capabilities in a high-cost environment. Through the investigation of critical operations capabilities, it is possible for managers to find new areas of competitiveness, as well as to understand their current areas of excellence. The study makes several contributions, such as the identification of operations capabilities, their investigation and validation in a specific environment.
\end{abstract}

Keywords: capabilities, case study, high-cost environment, location decision, reshoring

\section{INTRODUCTION}

Many studies have been conducted concerning the shift of manufacturing from high-cost to low-cost environments and vice versa (Gurtu et al., 2019; Kerkhoff et al., 2017; Ketokivi et al., 2017). This relocation process is sustained by the notion that there is a compelling advantage in locating manufacturing in low-cost environments. This has intensified the controversy over manufacturing located in high-cost environments, generating various issues (Spring et al., 2017; Yin et al., 2017). One of the issues concerns the struggle in deciding whether these manufacturing firms should follow the offshoring movement or try to compete from their current location (Brandon-Jones et al., 2017; Hilletofth, 2011; Eriksson et al., 2018; Ketokivi et al., 2017).

Recently, reshoring, a relocation process whereby manufacturing is moved back to 'the home country', has been gaining more attention (Engström et al., 2018; White and Borchers, 2016; Wiesmann et al., 2017). The reshoring movement emphasizes the ability to manufacture competively in a high-cost environment. Therefore, it is of the utmost importance to understand how firms located in a high-cost environment should compete and what is significant for the winning operations strategies in this specific environment (Brandon-Jones et al., 2017; Ketokivi et al., 2017). Developing a winning operations strategy requires understanding the competitive advantage, which is the distinctive edge the firm seeks to establish (Barney, 1991; Robbins and Coulter, 2012). Competitive advantage can be derived from capabilities that the firm has developed. This represents the company's actual, or realized, competitive strength relative to primary competitors in its target markets (Robbins and Coulter, 2012; Rosenzweig et al., 2003). The competitive success of a firm depends on its ability to identify, develop and continuously improve operations capabilities that provide superior value to customers (Koufteros et al., 2002).

Empirical research has shown that the development of operations capabilities can help to achieve a higher level of performance along different dimensions such as cost, quality, time and flexibility (Boyer and Lewis, 2002; Hilmola et al., 2015; Rosenzweig et al., 2003). While there are notable exceptions (e.g. Größler and Grübner, 2006), 
little emphasis in the literature has been placed on critical operations capabilities for competitive manufacturing in a high-cost environment, and there are few current frameworks of operations capabilities that can accurately capture today's market situation.

Many researchers in the operations management field have conducted studies in which they examine the operations strategy concept and identify critical priorities and operations capabilities (Frohlich and Dixon, 2001; Größler and Grübner, 2006; Hallgren, 2007; Leong et al., 1990). Despite the abovementioned studies, firms located in a highcost environment still face great difficulties managing competition from firms located in a low-cost environment. Although this problem is generally acknowledged, the current literature contains a gap concerning the identification and development of operations capabilities in a high-cost environment. Existing contributions provide only a rather limited overview of this context. Yet, it is fundamental to understand the critical operations capabilities for competitive manufacturing in a high-cost environment in order to formulate winning operations strategies (Sansone et al., 2017).

The purpose of this study is thus to investigate critical operations capabilities in a high-cost environment. To do so, a multiple case study was conducted, involving five manufacturing firms located in Sweden. The manufacturing firms operate in different sectors and serve different customer segments. However, all case companies operate in the same environment. The breadth of the sample enables a cross-case analysis of critical operations capabilities.

The reminder of this paper is structured as follows: a background to critical operations capabilities in a high-cost environment is presented in Section 2, which includes an overview of competitive advantage, operations strategy and the external environment. A framework of critical operations capabilities in a high-cost environment is introduced in Section 3. The research method is explained in Section 4, including data collection and analysis. Thereafter, the empirical findings are presented in Section 5. The findings are discussed and linked to the literature in Section 6. Finally, the study is concluded in Section 7.

\section{BACKGROUND TO CRITICAL OPERATIONS CAPABILITIES IN A HIGH-COST ENVIRONMENT}

Competitive advantage is planned into the business strategy and is achieved through a value-creation strategy desired by customers, but not implemented by any current or potential competitor (Barney, 1991). Such an advantage can be created by offering customers superior value, either by providing the same benefits as competitors at lower cost (cost advantage), or by providing benefits that exceed those of the competing offerings (value advantage) or both (Barney, 1991; Porter, 1996). The fundamental strategies for creating a competitive advantage are usually referred to as cost-leadership and differentiation (Porter, 1980). The source of the advantage lies found in the ability to differentiate from the competition with regard to products and customer service, and in the ability to operate at lower cost with less resources (Christopher, 1998). This is achieved by organizing the firm around how customer value is created and delivered efficiently, and how these processes can be coordinated and managed (Hilletofth, 2010).

Competitive advantage is formulated as part of the business strategy and is subsequently applied to the functional operations strategy (Hayes and Wheelwright, 1984; Hill, 1995; Flynn et al., 1999; Frohlich and Dixon, 2001; Koufteros et al., 2002; Prester et al., 2016). Two core elements are central to the formulation of an operations strategy (Dangayach and Deshmunk, 2001; Leong et al., 1990; Martín Peña and Díaz Garrido, 2008; Platts et al., 1998). The first element (competitive priorities) is a statement of what the operations function must accomplish (referred to as the tasks, objectives or priorities) and can be defined as the capabilities that the operations unit must have in order to compete successfully, given its overall business strategy (Hayes and Wheelwright, 1984; Miller and Roth, 1994; Platts et al., 1998). In other words, these are the intended capabilities on which future emphasis should be placed (Größler and Grübner, 2006). The second element in the formulation of an operations strategy (operations decisions) is the pattern of decisions that a firm makes, which in turn determines the actual capabilities of the operations system (Hayes and Wheelwright, 1984; Miller and Roth, 1994; Platts et al., 1998). The firm makes decisions and then acts in terms of operations, given the specified priorities, available resources, and this results in various operations capabilities (Anderson et al., 1989; Größler and Grübner, 2006). The operations decisions are based on specialized knowledge and the use of constrained resources. Management makes decisions under the regime of finite resources where it is not possible to maximize all capabilities (Größler and Grübner, 2006). Therefore, operations capabilities emphasize the role of strategic management in adapting, integrating, and configuring skills and resources to match customer expectations (Koufteros et al., 2002).

The external environment in which the firm operates, among other things, impacts on the formulation of competitive advantage. One way to distinguish between aspects of the external environment is to differentiate between high-cost and low-cost environments. Yet, the distinction between these two is generally not well defined in the literature. One common way to determine whether a country is high or low-cost is to use some form of priceparity index (Green and Ross, 2012). However, the differentiation between high-cost and low-cost environments is also related to different ways of competing, according to the cost situation. In a low-cost environment, the basis for success is to compete on price and to have the lowest cost. This means focusing on efficiency, doing what you do as well as possible. This often results in a focus on productivity and reduces the risk of introducing unnecessary new things into the operations system (Roos and Kennedy, 2014). In a high-cost environment, on the other hand, the basis for success is to compete on superior value. This means focusing on effectiveness (performing the right operations or activities). This often leads to a focus on innovation and the identification of smarter ways to perform operations or activities (Roos and Kennedy, 2014). 


\section{CRITICAL OPERATIONS \\ CAPABILITIES IN A HIGH-COST ENVIRONMENT}

A literature review was conducted to derive critical operations capabilities for competitive manufacturing. The objective was to capture current research and present a holistic view of critical operations capabilities. In total, 22 critical capabilities for competitive manufacturing were identified in the review (Table 1). This is a considerable extension to popular frameworks in the existing literature (e.g. Frohlich and Dixon, 2001; Miller and Roth, 1994). The environmental perspectives used in the literature (generic, high-cost, and low-cost environment) were also considered. The capabilities are discussed from a high-cost environment perspective below.

Table 1 Framework of operations capabilities

\begin{tabular}{|c|c|c|c|}
\hline Dimension & Capability & Definition & Supporting references \\
\hline \multirow{3}{*}{ Cost } & Cost efficiency & The ability to provide products at low cost & $\begin{array}{l}\text { Bolivar Cruz and Espino Rodriguez, } \\
\text { 2008; Kaipia and Turkulainen, } 2017\end{array}$ \\
\hline & Resource efficiency & $\begin{array}{l}\text { The ability to maximize the utilization of } \\
\text { process resources (machinery and human) }\end{array}$ & Chi, 2010; Ward et al.,1995 \\
\hline & Process efficiency & The ability to maximize the process output & Ling Tay, 2016 \\
\hline \multirow{4}{*}{ Quality } & Product quality & $\begin{array}{l}\text { The ability to provide durable, high- } \\
\text { performance products }\end{array}$ & $\begin{array}{l}\text { Christiansen et al., 2003; Ward et } \\
\text { al., } 1995\end{array}$ \\
\hline & Process quality & $\begin{array}{l}\text { The ability to provide products/ services with } \\
\text { consistent quality }\end{array}$ & $\begin{array}{l}\text { Größler and Grübner, 2006; Hong } \\
\text { et al., } 2010\end{array}$ \\
\hline & $\begin{array}{l}\text { Delivery } \\
\text { dependability }\end{array}$ & The ability to deliver on time & $\begin{array}{l}\text { Frohlich and Dixon, 2001; Größler } \\
\text { and Grübner, } 2006\end{array}$ \\
\hline & Brand quality & $\begin{array}{l}\text { The ability to build a strong and positive } \\
\text { company image }\end{array}$ & $\begin{array}{l}\text { Christiansen et al., 2003; Frohlich } \\
\text { and Dixon, } 2001\end{array}$ \\
\hline \multirow{2}{*}{ Time } & Delivery time & The ability to deliver in a short time frame & $\begin{array}{l}\text { Chung and Swink, 2009; } \\
\text { Da Silveira, } 2005\end{array}$ \\
\hline & Time to market & $\begin{array}{l}\text { The ability to have short time frame from } \\
\text { product development to market introduction }\end{array}$ & $\begin{array}{l}\text { Al Serhan, 2015; Gao and Tian, } \\
2014\end{array}$ \\
\hline \multirow{6}{*}{ Flexibility } & Product flexibility & $\begin{array}{l}\text { The ability to customize products based on } \\
\text { customer requirements }\end{array}$ & $\begin{array}{l}\text { Bouranta and Psomas, 2017; Ferrer } \\
\text { et al., } 2011\end{array}$ \\
\hline & Product line flexibility & $\begin{array}{l}\text { The ability to provide a wide range of } \\
\text { products with different features }\end{array}$ & $\begin{array}{l}\text { Pooya and Faezirad, } 2017 \\
\text { Sarmiento et al., } 2016\end{array}$ \\
\hline & Volume flexibility & $\begin{array}{l}\text { The ability to respond to changes in market } \\
\text { demand }\end{array}$ & $\begin{array}{l}\text { Garo and Guimaraes, 2018; } \\
\text { Hemmati et al., } 2016\end{array}$ \\
\hline & $\begin{array}{l}\text { Production mix } \\
\text { flexibility }\end{array}$ & $\begin{array}{l}\text { The ability to change the product mix in } \\
\text { manufacturing }\end{array}$ & Ho et al., 2016; Malek et al., 2015 \\
\hline & Labor flexibility & $\begin{array}{l}\text { The ability of employees to perform different } \\
\text { types of tasks }\end{array}$ & Chi, 2010; Ward et al, 1995 \\
\hline & Delivery flexibility & $\begin{array}{l}\text { The ability to change delivery times and } \\
\text { quantities within the agreed upon delivery } \\
\text { time }\end{array}$ & Chi, 2010; Ho et al., 2016 \\
\hline \multirow{5}{*}{ Innovation } & Product innovation & $\begin{array}{l}\text { The ability to develop and introduce new } \\
\text { products }\end{array}$ & $\begin{array}{l}\text { Bulak and Turkyilmaz, 2014; Zhao } \\
\text { et al., } 2002\end{array}$ \\
\hline & Service innovation & $\begin{array}{l}\text { The ability to develop and introduce new } \\
\text { services }\end{array}$ & $\begin{array}{l}\text { Diaz-Garrido et al., 2011; Zhang et } \\
\text { al., } 2008\end{array}$ \\
\hline & Process innovation & $\begin{array}{l}\text { The ability to develop and implement new } \\
\text { processes }\end{array}$ & Guimaraes, 2014; Lau et al., 2013 \\
\hline & $\begin{array}{l}\text { Technology } \\
\text { innovation }\end{array}$ & $\begin{array}{l}\text { The ability to develop and implement new } \\
\text { technologies }\end{array}$ & $\begin{array}{l}\text { Da Silva et al., 2009; Gao and Tian, } \\
2014\end{array}$ \\
\hline & Market innovation & $\begin{array}{l}\text { The ability to find and exploit new markets } \\
\text { and opportunities }\end{array}$ & $\begin{array}{l}\text { Hong et al., 2010; Koufteros et al., } \\
2002\end{array}$ \\
\hline \multirow{2}{*}{ Sustainability } & $\begin{array}{l}\text { Product } \\
\text { sustainability }\end{array}$ & The ability to provide sustainable products & $\begin{array}{l}\text { Longoni and Cagliano, 2015; Pooya } \\
\text { and Faezirad, } 2017\end{array}$ \\
\hline & $\begin{array}{l}\text { Process } \\
\text { sustainability }\end{array}$ & $\begin{array}{l}\text { The ability to manufacture products in a } \\
\text { sustainable manner }\end{array}$ & $\begin{array}{l}\text { Espino-Rodríguez, 2016; Longoni } \\
\text { and Cagliano, } 2015\end{array}$ \\
\hline
\end{tabular}


The first dimension covers capabilities related to cost. Cost reduction is a dimension covering all of the firms' areas, although it is certainly true that most of the costs of the product or service are generated in the production area (Bolivar Cruz and Espino Rodriguez, 2008). Firms that emphasize the cost dimension, usually focus on achieving or maintaining the lowest production, raw material and labor costs (Chi, 2010; Kaipia and Turkulainen, 2017; Ward et al., 1995). Companies that develop cost capabilities usually adopt lean strategies. However, it is no longer enough for companies located in a high-cost environment to compete only on cost (lean production); market instability requires companies to develop innovation-related capabilities far beyond the mechanisms involved in cost-related strategies (Chi, 2010; Yusuf and Adeleye, 2002).

The second dimension covers capabilities related to quality. The traditional observance of a quality dimension reflects a focus on providing high-performance products (Christiansen et al., 2003; Ward et al., 1995), and reliable products (Größler and Grübner, 2006; Hong et al., 2010). By providing high-quality products, a firm can improve its image (Christiansen et al., 2003; Frohlich and Dixon, 2001; Longoni and Cagliano, 2015). Quality is considered the most critical dimension in a high-cost environment (Gelders et al., 1994; Kaipia and Turkulainen, 2017). If quality capabilities are well developed, effectively controlled and constantly improved, companies located in a high-cost environment should be able to put more emphasis on programs that enhance flexibility and time-related capabilities (Corbett, 1996).

The third dimension covers capabilities related to time. A time-based strategy emphasizes the notion that firms should compete by providing fast deliveries of products to customers (Chung and Swink, 2009; Da Silveira, 2005), and by reducing time to market (Al Serhan, 2015; Gao and Tian, 2014). In time-based strategies, firms may not have the least costly nor the highest quality product but are able to compete on the basis of a time advantage (Chi, 2010). Successful firms in a high-cost environment respond to high competition by emphasizing differentiation through capabilities like delivery time and time to market (Ward et al., 1995). Reducing time to market has multiple benefits, including a higher market share, increased profits, and shorter breakeven times (Jayaram and Narasimhan, 2007). Time to market and short delivery times are critical in a high-cost environment, due to the rapid technological evolution and short product life cycles (Gelders et al., 1994; Szász and Demeter, 2014).

The fourth dimension covers capabilities related to flexibility, a proactive dimension, meaning that companies adjust their resources to respond to changing circumstances, with little negative impact on time and cost (Ferrer et al., 2011). Flexibility in manufacturing companies has traditionally been achieved at high-cost by using genericpurpose machines instead of more efficient special purposebuilt machines and more highly-skilled workers (Chi, 2010, Ward et al., 1995). From a high-cost-environment perspective, increasing environmental complexity and dynamism have caused firms to place more emphasis on flexibility (Chi et al., 2009). Increasing environmental hostility has pushed high-performing firms to treat quality, time and flexibility as priorities (Chi et al., 2009). It is evident that successful firms located in high-cost environments focus on the development of flexibility capabilities whenever they need to respond to labor shortages (Ward et al., 1995).

The fifth dimension covers capabilities related to innovation. In the literature, innovation is seen not only as an important dimension for achieving a competitive advantage, but also as a necessity (Ferrer et al., 2011). Innovation is the creation of new combinations, which could be, for example, new products or services (Bulak and Turkyilmaz, 2014, Zhao et al., 2002). From a high-cost-environment perspective, firms tend to implement strategies that allow them to compete through differentiation. Indeed, many firms differentiate themselves through the development of innovation and quality capabilities (Koufteros et al., 2002), which allow them to charge premium prices. Innovation capabilities are also implemented so as to achieve a competitive advantage (Lau et al., 2013).

The sixth dimension covers capabilities related to sustainability. Based on the definition of sustainable development, sustainability can be described as the use of natural resources in such way that the present generation meets its needs, without compromising future generations ability to meet their own needs (Longoni and Cagliano, 2015). It is emphasized that firms should focus on providing environmentally friendly products (Pooya and Faezirad, 2017) and consume natural resources at a lower rate, or generate limited emissions during the manufacturing process (Espino-Rodríguez, 2016). However, these capabilities do not have strong support in the literature, at least not from a high-cost-environment perspective. This may be related to the high complexity of these capabilities, which require a mature approach and the availability of resources that not all firms have (Longoni and Cagliano, 2015).

\section{RESEARCH METHOD}

The research process is based on the investigation of critical operations capabilities in a high-cost environment. In order to investigate operations capabilities in a real setting and a specific context, this study adopts case study research. An overview of the research method is presented in Figure 1.

The benefits of adopting multiple case study research are related to the ability to focus on a 'case', retaining a holistic and real-world perspective and comparing the various cases included by encouraging the investigators to consider what is common across cases (Yin, 2014). Theoretical sampling was used in the study. In terms of selection, the investigators focused on manufacturing companies that were aiming to develop critical operations capabilities in a high-cost environment, while operating in different industries and sectors. The selection process resulted in five Swedish manufacturing companies (Table 2) 


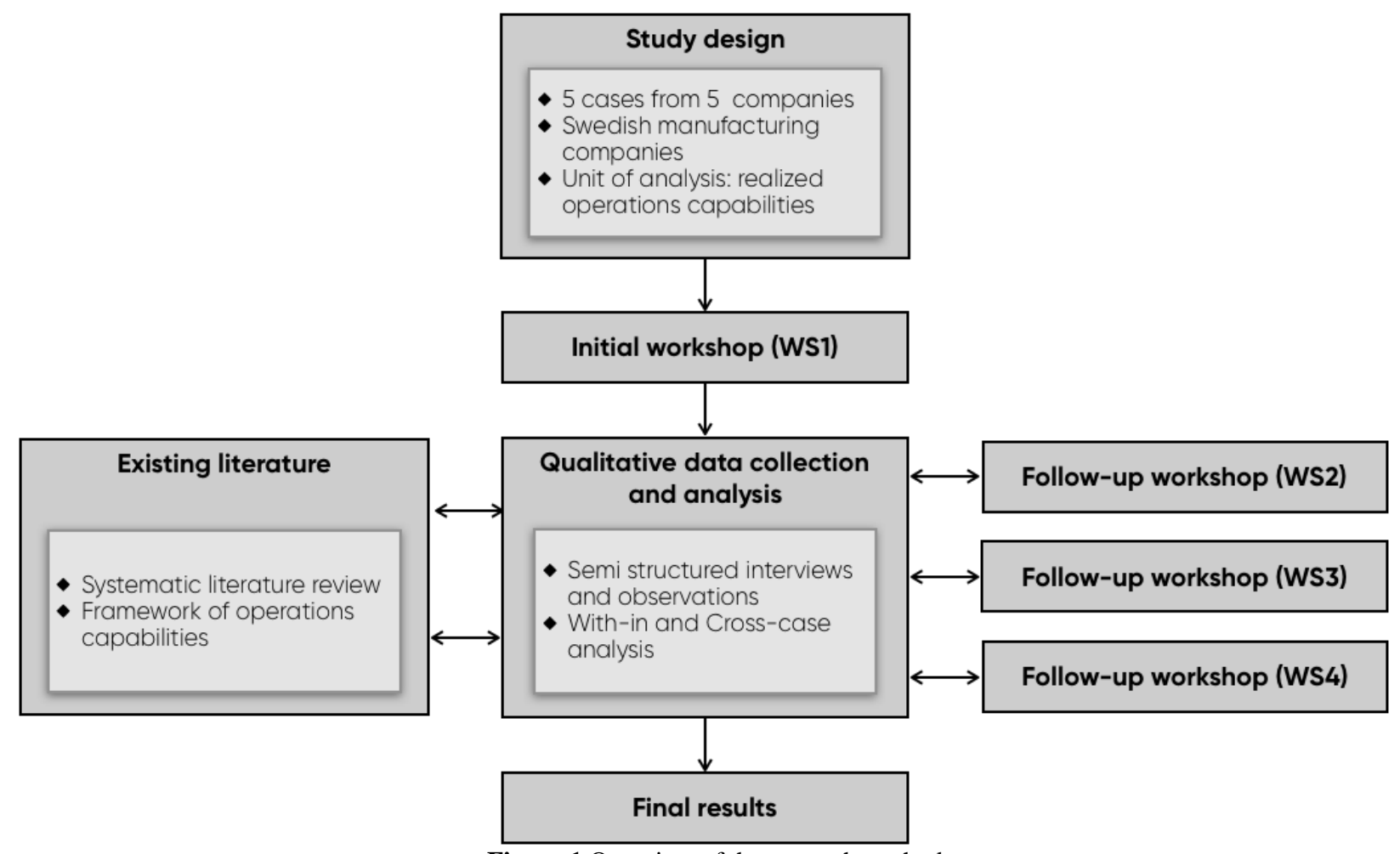

Figure 1 Overview of the research method

Table 2. Overview of companies selected

\begin{tabular}{|l|l|l|l|l|l|}
\hline & Company A & Company B & Company C & Company D & Company E \\
\hline Location & Sweden & Sweden & Sweden & Sweden & Sweden \\
\hline Type & Manufacturing & Manufacturing & Manufacturing & Manufacturing & Manufacturing \\
\hline Market & Global & Global & Global & Global & Global \\
\hline Product & Telecom & Laundry & Vehicle & Packaging & Office \\
\hline Turnover & 113,500 MSEK & 1,450 MSEK & 1,100 MSEK & 1,650 MSEK & 550 MSEK \\
\hline Employees & 17,000 & 480 & 560 & 330 & 230 \\
\hline
\end{tabular}

\subsection{Data Collection}

All companies were included in data collection, which included semi-structured interviews, workshops, observations, and documents. The semi-structured interviews were conducted with representatives from top and middle management at the respective companies (Table 3). The interviews provided an in-depth understanding of the operations strategy and operations capabilities implemented and developed within each company. In total, 51 semistructured interviews were conducted. The questions asked during the interviews covered various topics, including operations strategy and company capabilities, as well as improvement strategies and work in the company. The workshops gave an overview of different topics, for example the implemented operations strategies, challenges of a highcost environment, as well as a contextual understanding of the topic being studied. The observations focused on the manufacturing facilities, which helped the investigators to study the production systems of the companies, so as to contextualize the findings. Additional documents were provided by the companies, which yielded supplementary contextual information.

Table 3 Overview of interviews

\begin{tabular}{|c|c|c|c|c|c|c|}
\hline \multirow{2}{*}{\multicolumn{2}{|c|}{ Position in the company }} & \multirow{2}{*}{ Interview } & \multicolumn{4}{|c|}{ Workshops } \\
\hline & & & WS1 & WS2 & WS3 & WS4 \\
\hline \multirow{7}{*}{ 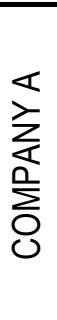 } & Logistic manager & 11 & $\mathrm{X}$ & - & - & - \\
\hline & Sourcing manager & 12 & $X$ & - & - & - \\
\hline & Supply chain manager & 13 & $X$ & - & - & $X$ \\
\hline & Line manager & 14 & $\mathrm{X}$ & - & - & - \\
\hline & Head of production line & 15 & - & - & - & - \\
\hline & Supply chain manager & 16 & - & - & - & - \\
\hline & Production planning manager & 17 & - & - & - & - \\
\hline
\end{tabular}


Table 3 Overview of interviews (cont')

\begin{tabular}{|c|c|c|c|c|c|c|}
\hline \multicolumn{7}{|c|}{ Position in the company } \\
\hline & Position in the company & Interview & WS1 & WS2 & WS3 & WS4 \\
\hline \multirow{7}{*}{ 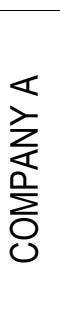 } & Production manager & 18 & - & - & - & - \\
\hline & Head of product introduction management & 19 & - & - & - & - \\
\hline & Improvement manager & 110 & - & - & - & - \\
\hline & Senior supply chain developer & 111 & - & - & - & - \\
\hline & Operational development manager & - & $\mathrm{X}$ & $\mathrm{X}$ & $\mathrm{X}$ & $\mathrm{X}$ \\
\hline & Operational excellence manager & - & $\mathrm{X}$ & $\mathrm{X}$ & $\mathrm{X}$ & $\mathrm{X}$ \\
\hline & Strategic supply manager & - & $\mathrm{X}$ & - & - & $\mathrm{X}$ \\
\hline \multirow{12}{*}{$\begin{array}{l}\sum_{\substack{\alpha \\
0}}^{\infty} \\
\sum_{0}\end{array}$} & CEO/Operations manager & 11 & $\bar{X}$ & $\bar{X}$ & $\bar{X}$ & - \\
\hline & Enablers director $R \& D$ & 12 & $\mathrm{X}$ & - & - & - \\
\hline & Quality manager & 13 & $\mathrm{X}$ & - & - & - \\
\hline & Technical manager & 14 & $x$ & - & $\mathrm{X}$ & $\mathrm{X}$ \\
\hline & Director global R\&D & 15 & $x$ & - & - & - \\
\hline & Logistics manager & 16 & $X$ & - & - & - \\
\hline & Finance director & 17 & - & - & - & - \\
\hline & Factory controller & 18 & $\mathrm{X}$ & - & - & - \\
\hline & Controller & 19 & - & - & - & - \\
\hline & Production engineering manager & 110 & - & - & - & - \\
\hline & Supply chain manager & 111 & - & - & - & - \\
\hline & Production development engineer & 112 & - & $X$ & $X$ & $X$ \\
\hline \multirow{10}{*}{ 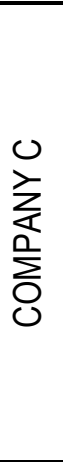 } & Quality manager & 11 & $\bar{X}$ & - & - & $\bar{X}$ \\
\hline & Plant manager & 12 & $\mathrm{X}$ & - & $\mathrm{X}$ & $\mathrm{X}$ \\
\hline & Purchasing manager & 13 & $X$ & - & $\mathrm{X}$ & - \\
\hline & Lean manager & 14 & $\mathrm{X}$ & $\mathrm{X}$ & $\mathrm{X}$ & $\mathrm{X}$ \\
\hline & Logistics manager & 15 & - & - & $\mathrm{X}$ & $\mathrm{X}$ \\
\hline & Project leader (NPD) & 16 & - & - & - & - \\
\hline & Marketing manager & 17 & - & - & $\mathrm{X}$ & - \\
\hline & Program manager & 18 & - & - & - & - \\
\hline & Finance manager & 19 & - & - & - & - \\
\hline & Production manager & - & - & - & - & $\mathrm{X}$ \\
\hline \multirow{10}{*}{$\begin{array}{l}\sum_{\substack{0 \\
0}} \\
\sum_{0}\end{array}$} & Supply chain manager & 11 & $\mathrm{X}$ & $\mathrm{X}$ & $\mathrm{X}$ & - \\
\hline & Production manager & 12 & $\mathrm{X}$ & $\mathrm{X}$ & - & $\mathrm{X}$ \\
\hline & Logistic manager & 13 & $\mathrm{X}$ & - & - & $\mathrm{X}$ \\
\hline & Production leader & 14 & $X$ & - & - & - \\
\hline & Planning manager & 15 & $x$ & - & - & - \\
\hline & Business director industry & 16 & - & - & - & - \\
\hline & Lean manager & 17 & - & - & - & - \\
\hline & Purchasing manager & 18 & - & - & - & - \\
\hline & Business director & 19 & - & - & - & - \\
\hline & Technical manager & 110 & $\mathrm{X}$ & - & - & - \\
\hline \multirow{9}{*}{ 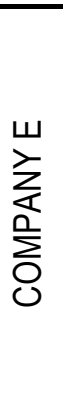 } & Technical and quality manager & 11 & $\bar{X}$ & $\bar{X}$ & - & - \\
\hline & Sourcing manager & 12 & $\mathrm{X}$ & - & - & - \\
\hline & Production engineer & 13 & $\mathrm{X}$ & - & - & - \\
\hline & Workshop manager & 14 & $\mathrm{X}$ & - & - & - \\
\hline & Technical product manager & 15 & $\mathrm{X}$ & - & - & - \\
\hline & CEO/Operations manager & 16 & $X$ & - & $\mathrm{X}$ & $\mathrm{X}$ \\
\hline & Planning manager & 17 & $\mathrm{X}$ & - & - & - \\
\hline & Production manager & 18 & $\mathrm{X}$ & - & - & - \\
\hline & Marketing manager & 19 & - & - & - & - \\
\hline
\end{tabular}




\subsection{Data Analysis}

The data analysis strategy adopted in this study is based on the link between the data collected in the case studies and the operations capabilities framework. The framework shaped, led and gave a sense of direction when analyzing the data (Dubois and Gadde, 2002). The qualitative data analysis began with a within case analysis. Each interview was recorded and transcribed. The investigators familiarized themselves with and analyzed the interview transcripts, and relevant information was extracted and included in the case study description. The interview data was structured and condensed in line with the existing literature and the framework of operations capabilities. As a result, it was possible to gain an overall view of the critical dimensions and operations capabilities in each case company. The qualitative data analysis continued with a cross-case analysis. The analysis focused on finding patterns, commonalities and differences between theory and data from the case companies. This was achieved by comparing data across cases for each of the dimensions and operations capabilities. Moreover, the data collected from the additional meetings and workshops were analyzed, and they added relevant information to the study.

\section{EMPIRICAL FINDINGS}

The systematic search for cross-case patterns is a key step in case research (Voss et al., 2002 p. 214). The patterns for this study are summarized in Table 4. All five case companies consider the dimensions of cost, quality, time, flexibility, innovation and sustainability as critical dimensions of operations capabilities. However, the emphasis differs between companies and dimensions. All the case companies seem to share many similarities, but very few differences in the process of developing capabilities.

Table 4 The empirical findings in relation to the literature (bold denotes new capability discovered in the empirical research)

\begin{tabular}{|c|c|c|c|c|c|c|c|c|}
\hline Dimension & Capability & Definition & A & B & C & D & E & Lit. \\
\hline \multirow{3}{*}{ Cost } & Cost efficiency & The ability to provide products at low cost & $\checkmark$ & $\checkmark$ & $\checkmark$ & $\checkmark$ & $\checkmark$ & $\checkmark$ \\
\hline & Resource efficiency & $\begin{array}{l}\text { The ability to maximize the utilization of process } \\
\text { resources (machinery and human) }\end{array}$ & $\checkmark$ & $\checkmark$ & $\checkmark$ & $\checkmark$ & $\checkmark$ & $\checkmark$ \\
\hline & Process efficiency & The ability to maximize the process output & $\checkmark$ & & $\checkmark$ & & & $\checkmark$ \\
\hline \multirow{6}{*}{ Quality } & Product quality & $\begin{array}{l}\text { The ability to provide durable, high-performance } \\
\text { products }\end{array}$ & $\checkmark$ & $\checkmark$ & $\checkmark$ & $\checkmark$ & $\checkmark$ & $\checkmark$ \\
\hline & Service quality & The ability to provide high-performance services & $\checkmark$ & $\checkmark$ & $\checkmark$ & & & \\
\hline & Process quality & $\begin{array}{l}\text { The ability to provide products/ services with } \\
\text { consistent quality }\end{array}$ & $\checkmark$ & $\checkmark$ & $\checkmark$ & $\checkmark$ & $\checkmark$ & $\checkmark$ \\
\hline & Delivery dependability & The ability to deliver on time & $\checkmark$ & $\checkmark$ & $\checkmark$ & $\checkmark$ & $\checkmark$ & $\checkmark$ \\
\hline & Brand quality & $\begin{array}{l}\text { The ability to build a strong and positive company } \\
\text { image }\end{array}$ & & $\checkmark$ & & $\checkmark$ & $\checkmark$ & $\checkmark$ \\
\hline & $\begin{array}{l}\text { Supplier } \\
\text { dependability }\end{array}$ & The ability to select and develop reliable suppliers & $\checkmark$ & $\checkmark$ & $\checkmark$ & & $\checkmark$ & \\
\hline \multirow[b]{2}{*}{ Time } & Delivery time & The ability to deliver in a short time frame & $\checkmark$ & $\checkmark$ & $\checkmark$ & $\checkmark$ & $\checkmark$ & $\checkmark$ \\
\hline & Time to market & $\begin{array}{l}\text { The ability to have short time frame from product } \\
\text { development to market introduction }\end{array}$ & $\checkmark$ & $\checkmark$ & $\checkmark$ & $\checkmark$ & $\checkmark$ & $\checkmark$ \\
\hline \multirow{7}{*}{ Flexibility } & Product flexibility & $\begin{array}{l}\text { The ability to customize products based on } \\
\text { customer requirements }\end{array}$ & $\checkmark$ & $\checkmark$ & $\checkmark$ & $\checkmark$ & $\checkmark$ & $\checkmark$ \\
\hline & Product line flexibility & $\begin{array}{l}\text { The ability to provide a wide range of products with } \\
\text { different features }\end{array}$ & $\checkmark$ & $\checkmark$ & $\checkmark$ & & $\checkmark$ & $\checkmark$ \\
\hline & Volume flexibility & The ability to respond to changes in market demand & $\checkmark$ & $\checkmark$ & $\checkmark$ & $\checkmark$ & $\checkmark$ & $\checkmark$ \\
\hline & $\begin{array}{l}\text { Production mix } \\
\text { flexibility }\end{array}$ & The ability to change the manufacturing product mix & $\checkmark$ & $\checkmark$ & $\checkmark$ & $\checkmark$ & $\checkmark$ & $\checkmark$ \\
\hline & Labor flexibility & $\begin{array}{l}\text { The ability of employees to perform different types } \\
\text { of tasks }\end{array}$ & $\checkmark$ & & $\checkmark$ & $\checkmark$ & $\checkmark$ & $\checkmark$ \\
\hline & Delivery flexibility & $\begin{array}{l}\text { The ability to change delivery times and quantities } \\
\text { within the agreed upon delivery time }\end{array}$ & $\checkmark$ & & $\checkmark$ & $\checkmark$ & $\checkmark$ & $\checkmark$ \\
\hline & Supplier flexibility & $\begin{array}{l}\text { The ability to select and develop responsive } \\
\text { suppliers }\end{array}$ & $\checkmark$ & $\checkmark$ & $\checkmark$ & & $\checkmark$ & \\
\hline \multirow{3}{*}{ Innovation } & Product innovation & The ability to develop and introduce new products & $\checkmark$ & $\checkmark$ & $\checkmark$ & $\checkmark$ & $\checkmark$ & $\checkmark$ \\
\hline & Service innovation & The ability to develop and introduce new services & & & & $\checkmark$ & $\checkmark$ & $\checkmark$ \\
\hline & Process innovation & $\begin{array}{l}\text { The ability to develop and implement new } \\
\text { processes }\end{array}$ & & & & $\checkmark$ & $\checkmark$ & $\checkmark$ \\
\hline
\end{tabular}


Table 4 The empirical findings in relation to the literature (bold denotes new capability discovered in the empirical research) (cont')

\begin{tabular}{|l|l|l|l|l|l|l|l|l|}
\hline Dimension & Capability & Definition & A & B & C & D & E & Lit. \\
\hline \multirow{5}{*}{ Innovation } & Technology innovation & $\begin{array}{l}\text { The ability to develop and implement new } \\
\text { technologies }\end{array}$ & $\checkmark$ & $\checkmark$ & $\checkmark$ & & $\checkmark$ & $\checkmark$ \\
\hline & Market innovation & $\begin{array}{l}\text { The ability to find and exploit new markets and } \\
\text { opportunities }\end{array}$ & & & $\checkmark$ & $\checkmark$ & $\checkmark$ \\
\hline & $\begin{array}{l}\text { Supply chain } \\
\text { innovation }\end{array}$ & $\begin{array}{l}\text { The ability to develop and implement new supply } \\
\text { chain solutions }\end{array}$ & $\checkmark$ & $\checkmark$ & & & $\checkmark$ & \\
\hline \multirow{5}{*}{ Sustainability } & Product sustainability & The ability to provide sustainable products & $\checkmark$ & $\checkmark$ & $\checkmark$ & $\checkmark$ & $\checkmark$ & $\checkmark$ \\
\hline & Process sustainability & $\begin{array}{l}\text { The ability to manufacture products in a sustainable } \\
\text { manner }\end{array}$ & $\checkmark$ & $\checkmark$ & $\checkmark$ & $\checkmark$ & $\checkmark$ & $\checkmark$ \\
\hline & $\begin{array}{l}\text { Supply } \\
\text { sustainability }\end{array}$ & $\begin{array}{l}\text { The ability to source and deliver products in a } \\
\text { sustainable manner }\end{array}$ & $\checkmark$ & $\checkmark$ & & & $\checkmark$ & \\
\hline
\end{tabular}

\subsection{Cost}

Cost is usually reduced by adopting various methods, like lean management, six sigma, continuous improvement and automation. The cost of employees is at least partly the higher cost that companies in high-cost environments have to face. In order to minimize this cost, some companies focus on automation while others invest in education, knowledge and workforce skills. Company B improved cost and resource efficiency by introducing modularization and automation in the productions line. Similarly, Company A noticed that cost and resource efficiency were improved after investing in the know-how of their own employees. "Different companies can own the same machines, but it's the knowledge of the employees that makes a big difference" (Head of the production line, Company A). Company B believes that the key to competitive production in a high-cost environment is to reduce labor cost. Generally, "the labor cost in a high-cost environment is ten times higher than other companies located in low-cost environment" (Operations manager, Company B). Moreover, Company A confirms that, in order to be competitive, the case company is working on improving process efficiency as part of lean and six sigma practices. In a similar fashion, Company $\mathrm{C}$ works indirectly on improving process efficiency by increasing automation in the production line. "We need more automated production lines in order to handle material flow more effectively" (Logistic manager, Company C). Process efficiency is also related to the concept of resource efficiency and productivity.

\subsection{Quality}

Quality is considered to be one of the key dimensions in the case companies. Specifically, Company B confirms that good quality products help to gain more trust from customers, and this is a crucial aspect in beating the competition. However, Company $\mathrm{C}$ argues that companies located in a low-cost environments are now also increasing the level of quality, and this represents a major threat for companies located in a high-cost environment. Two additional capabilities were identified in the empirical data, service quality and supplier dependability (highlighted in Table 4). Company A confirms that it is fundamental to offer good service to the customer. It is not enough to focus only on quality related to the product or process, it is equally important to understand the customer and provide a good service experience. In the future, a greater focus on the services provided is necessary in order to differentiate from the competitors. "We need to offer an overall solution to our customers, which includes a good service" (Manager material handling and logistics, Company A). Company B emphasizes that it is important to provide a good quality product including a flawless experience to the customer, which includes good support and service, while Company $\mathrm{C}$ stresses the significance of being service-minded. Moreover, Company A believes that it is essential to always maintain a supply chain perspective in the context of offering good quality to the customer. It is important to build strong bonds with each supplier, which should lead to strong collaboration and high performance throughout all the supply chain. "We need to have a strong relationship with our suppliers if we want to optimize all our processes as a supply chain" (Workshop manager, Company E). This concept was also supported by Company B, with $\mathrm{C}$ and $\mathrm{E}$ also emphasizing the importance of choosing the right suppliers, which are reliable and offer good quality products.

\subsection{Time}

Another common denominator between the case companies is related to the time dimension. A short delivery time and rapid time to market are usually adopted by all the case companies. Fast delivery can be achieved by locating facilities closer to the customers. The main strategy for Company $\mathrm{C}$ is to establish facilities in most of the major customer areas around the world. This location strategy supports the company in being more responsive and able to deliver the products faster to customers. "We have a global footprint; this means we can be found anywhere outside Sweden. Being close to our customers is highly important" (Plant manager, Company C). However, some case companies prefer to focus on reducing lead time through lean practices. For example, Company D has a really short lead time, which constitutes a major advantage. "We receive an order during day one, we process the order during day two and already during day three, we are ready to ship to the customer" (Purchasing manager, Company D). Company D is able to have short lead times, also because of the availability of safety inventory. However, the company is also working on finding new and suitable, cost-efficient logistics solutions. Company $\mathrm{E}$ believes that more improvements are needed concerning delivery time and time to market. The case company nowadays needs to be able to provide short delivery lead-times. "It's really important to 
make sure that the customers get their products very fast, which is something that we are focusing on a lot" (Production engineer, Company E).

\subsection{Flexibility}

Considerable emphasis is placed flexibility, and the case companies work on capabilities such as volume flexibility, production mix flexibility, product flexibility, delivery flexibility and labor flexibility. Much emphasis has also been put on labor flexibility. Employees are the "engine of the company" and, in order to make the most of this resource, efforts are dedicated to educating multi-skilled employees. It is recognized among all the case companies that such employees can help to improve the flexibility of the company. Company E confirms that having a flexible workforce is a great advantage: "We have a relatively high flexibility among our staff members, they are multiskilled and this makes our work much easier. Of course, there is always a need for improvements" (CEO/Operations manager, Company E). Company $\mathrm{C}$ supports this view by emphasizing that employees are a precious company resources and the key is to increase resource efficiency. "An important way of staying competitive is about how well you use the resources available, it is fundamental to utilize the employees' knowledge and skills" (Plant manager, Company C). A new capability related to flexibility was identified and stressed in the case study: namely supplier flexibility. Company A states that when working with flexibility is it vital to maintain a supply chain perspective. "We always like to have a strong bond with our suppliers, this is beneficial when it comes to improving overall supply chain flexibility" (Supply chain manager, Company A). This aspect of flexibility was also stressed in Companies B, C and D, which emphasized the importance of choosing the correct suppliers, which are flexible and fast in delivering their products.

\subsection{Innovation}

The higher competition has thrust the case companies towards more innovation. It is crucial to develop and introduce new products and technologies to the market, in order to be competitive. Company A introduces new products each week, enabled by a good R\&D team and planning. Company $\mathrm{C}$ adopts brainstorming activities for identifying areas of improvement in their products. The company believes that new products or new technologies can be created by incremental changes and improvements of already existing products or technologies. A new capability included in this dimension was identified in the case studies: supply chain innovation. Companies $\mathrm{C}$ and $\mathrm{D}$ emphasize the importance of collaborating with their suppliers and customers in order to improve already existing products or create and develop new ones. "We constantly work on improving our products, and develop new innovative solutions, and in order to do that, we collaborate with both our customers and suppliers" (Business director, Company D). Company E not only emphasizes the collaboration in the supply chain (as do Companies C and D), but also the role of communication for improving innovation in the entire supply chain. "We develop new products and technologies all the time; innovation is not only about this. Innovation is also about finding a new way to communicate with different actors in the supply chain. This strong communication is the key to the creating innovative products" (Marketing manager, Company E). Company B instead underlines the role of suppliers in improving innovation in the company. In order to succeed, it is important to choose the right suppliers with the right know-how.

\subsection{Sustainability}

It is recognized among the case companies that the sustainability dimension plays a key role in outdoing competitors. All case companies work actively on reducing the environmental impact of their products and also on reducing the energy consumption related to the manufacturing processes. Company $\mathrm{C}$ adopts continuous improvement as a tool for offering environmentally friendly products. Company D states that focusing on environment is beneficial as long as it supports cost reductions. A new capability related to sustainability was identified in the case studies: supply chain sustainability. When taking into consideration sustainability, it is important to consider every aspect from a supply chain perspective. Company A mainly emphasizes the importance of choosing the right suppliers which work sustainably and respect all environmental regulations. "We are really careful when it comes to sustainability, our suppliers process their products with a really low impact on the environment" (Supply chain manager, Company A). Companies B and E mainly emphasize the demand perspective. An awareness of sustainability issues has been increasing also from a customer perspective. "Many of our bigger customers have started to ask about how we ensure a low environmental impact in our processes, and whether our suppliers also respect environmental regulations. This is quite important for us; we do not want to lose our customers!" (Marketing manager, Company E).

\section{DISCUSSION}

The empirical findings and their relation to existing literature are shown in Table 4. While many of the cases correspond to the literature, some findings also diverge from earlier research. Only cost, quality, time and flexibility are considered to be the four basic dimensions or key dimensions (Avella et al., 2001; Hallgren, 2007). These four dimensions are discussed by Skinner (1969), Hayes and Wheelwright, (1984), Leong et al. (1990) among others. However, according to this study, innovation and sustainability seem to have a high criticality in the case companies.

In a high-cost environment, companies emphasize labor flexibility, finding strength in employees with skills such as openness to change, knowledge sharing, creativity, and autonomy (Camps et al., 2016). The main goal of companies in a high-cost environment is to have flexible employees who perform better under conditions of high turbulence. Employee flexibility as part of effective organizational learning has been considered fundamental to dealing with successfully environmental turbulence (Camps et al., 2016).

A new capability, service quality, was identified from the case studies. Companies located in high-cost environment need to differentiate themselves from those located in low-cost environments. One path to differentiation, identified in the empirical data, is to be 
service-minded. Offering a good service to the customer can be considered as a competitive advantage to the firm (Bolivar Cruz and Espino Rodriguez, 2008). It is important to emphasize the appropriate treatment of customers, making products easily obtainable to customers and providing them with effective after sales services (Bolivar Cruz and Espino Rodriguez, 2008). This reflects the need to implement differentiation strategies which are based on creating a value advantage (Christopher, 2000). For companies located in a high-cost environment, the cost-leadership route is barely available, which forces companies to seek a strategy of differentiation through service excellence (Christopher, 2000).

Companies in a high-cost environment seem to have a strong focus on the supply chain perspective. Four new capabilities have been identified in the case study: supplier dependability, supplier flexibility, supply chain innovation and supply chain sustainability. Companies in a high-cost environment do not compete as single entities, but as supply chains (Christopher et al., 2006). Several aspects are highlighted from the empirical findings, for example high quality through the overall supply chain; high flexibility between all actors; strong bonds and collaboration within the supply chain for improving innovation and building sustainable supply chains.

It has long been recognized that operations strategy should be tailored to the criteria required by customers (Christopher et al., 2006; Hill, 1993). However, as mentioned by Christopher et al. (2006), this idea of aligning the firm's operations with market requirements has not always been extended to the overall supply chain. Decisions taken at the single-firm level can have an impact on the overall supply chain level; for example, just-in-time delivery and a reduced delivery time can in turn, reduce the cost and inventory at the firm level, but increase cost and inventory at the supplier level. To avoid such issues is fundamental to adopt a holistic approach to the supply chain (Christopher $e t$ al., 2006) also when developing specific operations capabilities.

Turbulent and unpredictable markets are becoming the norm as life cycles shrink and competitive forces create additional uncertainty; the high risk related to slow delivery, and rigid supply chains have become obsolete (Christopher, 2000). It is clear that this current situation has forced companies to look at how their supply chains are structured and managed. The empirical data suggests that the key ensuring survival in this turbulent market is through the creation of responsive (agile) supply chains. As stated by Christopher (2000), it is essential for responsible supply chains is to focus on flexibility.

The empirical data also emphasized the increased need for cooperation among partnering companies in the supply chain. The most successful companies seem to be those that have carefully linked their internal processes to external suppliers and customers in unique supply chains (Frohlich and Westbrook, 2001; Seuring and Müller, 2008). Upstream and downstream integration with suppliers and customers is an important element for operations strategies; the higher the level of supply chain integration, the higher the level of performance of a supply chain (Frohlich and Westbrook, 2001).

The increased need for cooperation among partnering companies is also emphasized when developing sustainable supply chains. Compared to all other capabilities discussed in the case companies, those related to sustainability received the least emphasis during interviews. This could be related to the high complexity of these capabilities (Longoni and Cagliano, 2015) and of the development of sustainable supply chains. One consequence of sustainability for companies and supply chains is the broader set of economic, environmental and social norms and criteria that needs to be met (Elkington, 2002; Seuring and Müller, 2008). However, an important matter identified in the empirical data is related to what exactly triggers companies in high-cost environment to focus on sustainability issues, namely a strong awareness of sustainability issues characterizing the current market. Customers and government put a lot of pressure on companies located in high-cost environments, pressure that is subsequently transferred to the overall supply chain. Hence, it is quite common that the focal company has to take a larger part of the supply chain into account, which means collecting information on the environmental performance of the single production line, as well as on the performance of the main suppliers (Seuring and Müller, 2008). For practitioners, the strong emphasis on the sustainability dimension is associated with the fact that customer demands have changed over time and companies need to be ready to adapt, in order to remain competitive. Practitioners need to develop capabilities that can help them provide sustainable products and also reduce the environment impact of their processes.

This study provides empirical evidence on critical operations capabilities in a high-cost environment and on the notion that there is an undeniable advantage in locating manufacturing in this specific context. The research stresses that other issues than cost are becoming increasingly important to creating a competitive advantage. This could also be linked to the ongoing reshoring movement, where most of the drivers are found outside of the cost dimension, including quality, flexibility and time issues (Engström et al., 2018). More specifically, reshoring firms try to focus on supplier integration and dependability, reducing the risk of late deliveries through increased delivery-time capability, also increasing responsiveness due to closer customer proximity (Benstead et al., 2017).

Due to the dynamic nature of these capabilities, there is a strong need to investigate operations capabilities to better align with the current market. Previous literature has shown that there have generally been four dimensions of operations capabilities, namely cost, quality, delivery, and flexibility (Avella et al., 2001; Hallgren, 2007; Hayes and Pisano, 1994; Leong et al., 1990; Skinner, 1969). In addition to these four dimensions, Sansone et al. (2017) included two additional ones, innovation and sustainability. Through this study, these dimensions find support in a high-cost environment. The findings demonstrated that these capabilities need to be updated continuously, and that the external environment in which they are developed can affect the selection and establishment of specific capabilities. 
Companies located in different environments can emphasize the development of various capabilities. Hence, researchers investigating operations capabilities could adopt the framework of operations capabilities developed in this study as a tool for future comparison. Moreover, new operations capabilities have been identified on which the scientific community need to focus. Additional knowledge can still be created in order to support practitioners in developing these new operations capabilities, and a supply chain perspective is needed in order to achieve a competitive advantage.

\section{CONCLUSIONS AND FURTHER RESEARCH}

This study leads to several conclusions and makes various contributions. The research shows that companies develop several operations capabilities, in order to be more competitive in a high-cost environment. These capabilities are related to various dimensions, which are cost, quality, time, flexibility, innovation and sustainability. The study also revealed the importance of new operations capabilities: service quality, supplier dependability, supplier flexibility, supply chain innovation, and supply chain sustainability. The identification of these new capabilities revealed a strong emphasis on service and the importance of a supply chain perspective. Companies in a high-cost environment constantly work with supply chain integration, so as to both improve performance and build sustainable supply chains. In addition, companies in a high-cost environment achieve a competitive advantage through differentiation strategies which are based on creation of a value advantage through tailored services, reliability and high responsiveness. These findings are in line with existing supply chain differentiation research (e.g., Hilletofth, 2009).

This study contributes to the ongoing process of gaining knowledge (Eriksson, 2015) on operations capabilities as part of the operations strategy, which are dynamic and based on the circumstances (Frohlich and Dixon, 2001). This demonstrates how operations capabilities and their dimensions keep changing over time. The investigation has underlined the dynamic nature of operations capabilities, the latter needing to be updated according to the environment in which they are developed. The capabilities investigated in this study can aid researchers and firms in gaining a better understanding of the operations strategy concept, through the clarification of critical operations capabilities. The study makes several contributions, such as identification of operations capabilities, their investigation and validation in a specific environment.

As in any research, there are limitations to the findings generated. All the capabilities included in the framework are considered critical by the representatives of the case companies, but this does not necessarily mean that these capabilities are critical in a high-cost environment. Since the sample was limited to five Swedish manufacturing companies, a large-scale investigation of critical operations capabilities in a high-cost environment is still needed. Also, in this study, the investigators did not take into consideration the size of the companies, the specific industry and the products offered. Thus, different research proposals are suggested for further research. The first concerns a large- scale investigation of critical operations capabilities in a high-cost environment. Survey-based studies are more suitable for generating data from which generalizations can be made. It would be interesting to include a larger sample of companies located in a high-cost environment and evaluate the framework of operations capabilities in the specific context. This would contribute to the generalizability of conclusions drawn. The second research proposal concerns the investigation of critical operations capabilities in a low-cost environment. The duplication of this study in a different context could help to understand its relevance and also to find similarities and differences between low and high-cost environments. Companies would benefit from such a study by gathering more information about the two different environments. This would help them in the formulation of a winning operations strategy or by guiding them through a hypothetical relocation process. The third research proposal concerns the investigation of critical operations and their performance implications. Prior empirical research has shown that the development of operations capabilities can aid in achieving the highest level of performance along different dimensions such as cost, quality, time and flexibility (Boyer and Lewis, 2002; Rosenzweig et al., 2003). In this context, it is firstly important to set a measurement and assessment tool for each operations capability and dimension. Secondly, it would be possible to find a link between operations capabilities and the company's operational and organizational performances.

\section{REFERENCES}

Al Serhan, Y.N., Julian, C.C., and Ahmed, Z.U. (2015), Using time to gain competitive advantage: a framework and analysis of propositions, International Journal of Commerce and Management, 25(4), pp. 456-465.

Anderson, J.C., Cleveland, G., and Schroeder, R.G. (1989), Operations strategy: a literature review, Journal of Operations Management, 8(2), pp. 133-158.

Avella, L., Fernández, E., and Vázquez, C.J. (2001), Analysis of manufacturing strategy as an explanatory factor of competitiveness in the large Spanish industrial firm, International Journal of Production Economics, 72(2), pp. 139-157.

Barney, J. (1991), Firm resources and sustained competitive advantage, Journal of Management, 17(1), pp. 99-120.

Benstead, A., Stevenson, V., and Hendry, M. (2017), Why and how do firms reshore? A contingency-based conceptual framework, Operations Management Research, 10(3), pp. 85-103.

Bolivar Cruz, A.M., and Espino Rodríguez, T.F. (2008), An analysis of operations strategy in the food and beverage sector, International Journal of Services and Operations Management, 4 (1), pp. 102-124.

Bouranta, N. and Psomas, E., (2017), A comparative analysis of competitive priorities and business performance between manufacturing and service firms, International Journal of Productivity and Performance Management, 66(7), pp. 914931.

Boyer, K.K. and Lewis, M.W. (2002), Competitive priorities: investigating the need for trade-offs in operations strategy, Production and Operations Management, 11(1), pp. 9-20.

Brandon-Jones, E., Dutordoir, M., Frota Neto, J. Q., and Squire, B., (2017), The impact of reshoring decisions on shareholder wealth, Journal of Operations Management, 49-51, pp. 3136. 
Bulak, M.E., and Turkyilmaz, A. (2014), Performance assessment of manufacturing SMEs: A frontier approach, Industrial Management \& Data Systems, 114(5), pp. 797-816.

Camps, J., Oltra, V., Aldas-Manzano, J., Buenaventura-Vera, G., and Torres-Carballo, F. (2016), Individual performance in turbulent environments: the role of organizational learning capability and employee flexibility, Human Resource Management, 55(3), pp. 363-383.

Chi, T. (2010), Corporate competitive strategies in a transitional manufacturing industry: an empirical study, Management Decision, 48(6), pp. 976-995.

Chi, T., Kilduff, P.P.D., and Gargeya, V.B. (2009), Alignment between business environment characteristics, competitive priorities, supply chain structures, and firm business performance, International Journal of Productivity and Performance Management, 58(7), pp. 645-669.

Christiansen, T., Berry, W.L., Bruun, P., and Ward, P. (2003), A mapping of competitive priorities, manufacturing practices, and operational performance in groups of Danish manufacturing companies, International Journal of Operations and Production Management, 23(10), pp. 11631183.

Christopher, M. (1998), Logistics and Supply Chain Management: Strategies for Reducing Costs and Improving Services, Pitman Publishing, London.

Christopher, M. (2000), The agile supply chain: competing in volatile markets", Industrial Marketing Management, 29, pp. 37-40.

Christopher, M.; Peck, H., and Towill, D. (2006), A taxonomy for selecting global supply chain strategies, The International Journal of Logistics Management, 17(2), pp. 277-287.

Chung, W., and Swink, M. (2009), Patterns of Advanced Manufacturing Technology utilization and Manufacturing capabilities, Production and Operations Management, 18(5), pp. 533-545.

Corbett, L. M. (1996), A comparative study of the operations strategies of globally- and domestically-oriented New Zealand manufacturing firms, International Journal of Production Research, 34(10), pp. 2677-2689.

Da Silva, E.M., Jabbour, C.J.C., and Santos, F.C.A., (2009), Integrating environmental management and manufacturing strategy: An emerging competitive priority, International Journal of Environmental Technology and Management, 10(3-4), pp. 397-411.

Da Silveira, G.J.C. (2005), Improving trade-offs in manufacturing: Method and illustration, International Journal of Production Economics, 95(1), pp. 27-38.

Dangayach, G.S., Deshmukh, S.G., (2001), Manufacturing strategy: Literature review and some issues, International Journal of Operations and Production Management, 21(7), pp. 884-932.

Díaz-Garrido, E., Martín-Peña, M.L., and Sánchez-López, J.M., (2011), Competitive priorities in operations: Development of an indicator of strategic position, CIRP Journal of Manufacturing Science and Technology, 4(1), pp. 118-125.

Dubois, A., and Gadde, L-E., (2002), Systematic combining: an abductive approach to case research, Journal of Business Research, 55(7), pp. 553-560.

Elkington, J., (2002), Cannibals with forks: the triple bottom line of $21^{\text {st }}$ century business, Oxford: Capstone.

Engström, G., Hilletofth, P., Eriksson, D., and Sollander, K. (2018), Drivers and barriers of reshoring in the Swedish manufacturing industry, World Review of Intermodal Transportation Research, 7(3), pp. 195-220

Eriksson, D. (2015), Lessons on knowledge creation in supply chain management, European Business Review, 27(4), pp. 346-368.
Eriksson, D., Hilletofth, P., Ellram, L.M., and Sansone, C. (2018), To offshore or reshore - the battle of data points, Supply Chain Management Review, 22(3), pp. 42-46.

Espino-Rodríguez, T.F. (2016), How hotels compete on the basis of competitive priorities and their relationship with infrastructural and structural decisions, Service Business, 10(4), pp. 737-773.

Ferrer, M., Santa, R., Storer, M., and Hyland, P. (2011), Competences and capabilities for innovation in supply chain relationships, International Journal of Technology Management, 56(2/3/4), pp. 272-289.

Flynn, B.B., Schroeder, R.G., and Flynn, E.J. (1999), World class manufacturing: an investigation of Hayes and Wheelwright's foundation, Journal of Operations Management, 17(3), pp. 249-269.

Frohlich, M.T., and Westbrook, R. (2001), Arcs of integration: an international study of supply chain strategies, Journal of Operations Management, 19, pp.185-200.

Frohlich, M.T., and Dixon, J.R., (2001), A taxonomy of manufacturing strategies revisited, Journal of Operations Management, 19(5), pp. 541-558.

Gao, T., and Tian, Y. (2014), Mechanism of supply chain coordination based on dynamic capability framework-the mediating role of manufacturing capabilities, Journal of Industrial Engineering and Management, 7(5), pp. 12501267.

Garo, W.R., Jr., and Guimarães, M.R.N., (2018), Competitive priorities and strategic alignment as mediators in the relationship between companies in the Brazilian automotive supply chain, South African Journal of Industrial Engineering, 29(1), pp. 184-194.

Gelders, L., Mannaerts, P., and Maes, J. (1994), Manufacturing strategy, performance indicators and improvement programmes, International Journal of Production Research, 32(4), pp. 797-805.

Green. R, and Roos, G. (2012), Australia's manufacturing future, available at:https://www.uts.edu.au/sites/default/files/Australia's_Man ufacturing_Future.pdf (accessed the $5^{\text {th }}$ of December, 2017).

Größler, A., and Grübner, A., (2006), An empirical model of the relationships between manufacturing capabilities, International Journal of Operations and Production Management, 26(5), pp. 458-485.

Gurtu, A., Saxen, R., and Sah, N. B. (2019), Offshoring decisions: a comprehensive and conceptual framework, Operations and Supply Chain Management, 12(3), pp. 118-128.

Hallgren, M. (2007), Manufacturing strategy, capabilities and performance, Doctoral thesis, Linköping University, Sweden.

Hay, M., and Williamson, P. (1991), Strategic Staircases: Planning the capabilities required for success, Long Range Planning, 24(4), pp. 36-43.

Hayes, R. H., and Pisano, G. P. (1994), Beyond world-class: The new manufacturing strategy, Harvard Business Review, 72(1), pp. 77-86.

Hayes, R.H., and Wheelwright, S.C., (1984), Restoring our Competitive Edge: Competing Through Manufacturing, Wiley, New York.

Hemmati, M., Feiz, D., Jalilvand, M. R., and Kholghi, I., (2016), Development of fuzzy two-stage DEA model for competitive advantage based on RBV and strategic agility as a dynamic capability, Journal of Modelling in Management, 11(1), pp. 288-308.

Hill, T. (1995), Manufacturing Strategy: Text and Cases, Macmillan, Basingstoke.

Hilletofth, P. (2009), How to develop a differentiated supply chain strategy, Industrial Management \& Data Systems, 109(1), pp.16-33. 
Hilletofth, P. (2010), Demand-supply chain management, Doctoral thesis, Chalmers University of Technology, Gothenburg, Sweden

Hilletofth, P. (2011), Demand-supply chain management: industrial survival recipe for new decade, Industrial Management \& Data Systems, 111(2), pp. 184-211.

Hilmola, O-P., Lorentz, H., Hilletofth, P., and Malmsten, J., (2015), Manufacturing strategy in SMEs and its performance implications, Industrial Management \& Data Systems, 115(6), pp. 1004-1021.

Ho, T. C. F., Ahmad, N. H., and Ramayah, T., (2016), Competitive Capabilities and Business Performance among Manufacturing SMEs: Evidence from an Emerging Economy, Malaysia, Journal of Asia-Pacific Business, 17(1), pp. 37-58.

Hong, P., Tran, O., and Park, K. (2010), Electronic commerce applications for supply chain integration and competitive capabilities: An empirical study, Benchmarking, 17(4), pp. 539-560.

Jayaram, J., and Narasimhan, R. (2007), The influence of new product development competitive capabilities on project performance, IEEE Transactions on Engineering Management, 54(2), pp. 241-256

Kaipia, R., and Turkulainen, V. (2017), Managing integration in outsourcing relationships-The influence of cost and quality priorities, Industrial Marketing Management, 61, pp. 114-129.

Kerkhoff, K., Kaul, K., Hilletofth, P., and Eriksson, D., (2017), Sourcing from China: a literature review of motivations, outcomes, problems, and solutions, Operations and Supply Chain Management, 10(4), pp. 226-239.

Ketokivi, M., Turkulainen, V., Seppälä, T., Rouvinen, P., and AliYrkkö, J., (2017), Why locate manufacturing in a high-cost country? A case study of 35 production location decisions, Journal of Operations Management, 49-51, pp. 20-30.

Koufteros, X. A., Vonderembse, M. A., and Doll, W. J. (2002), Examining the competitive capabilities of manufacturing firms, Structural Equation Modeling, 9(2), pp. 256-282.

Lau, A. K. W., Baark, E., Lo, W. L. W., and Sharif, N. (2013), The effects of innovation sources and capabilities on product competitiveness in Hong Kong and the Pearl River Delta, Asian Journal of Technology Innovation, 21(2), pp. 220-236.

Leong, G. K., Snyder, D. L., and Ward, P.T. (1990), Research in the process of manufacturing strategy, Omega, 18(2), pp. 109-122.

Ling Tay, H., (2016), Lean improvement practices: lessons from healthcare service delivery chains, IFAC Papers online, 49(12), pp. 1158-1163.

Longoni, A., and Cagliano, R. (2015), Environmental and social sustainability priorities: Their integration in operations strategies, International Journal of Operations and Production Management, 35(2), pp. 216-345.

Malek, N. A. A., Shahzad, K., Takala, J., Bojnec, S., Papler, D., and Liu, Y., (2015), Analyzing sustainable competitive advantage: Strategically managing resource allocations to achieve operational competitiveness, Management and Production Engineering Review, 6(4), pp. 70-86.

Miller, J.G., and Roth, A.V. (1994), A taxonomy of manufacturing strategies, Management Science, 40(3), pp. 285-304.

Platts, K.W., Mills, J.F., Bourne, M.C., Neely, A.D., Richards, A.H., and Gregory, M.J. (1998), Testing manufacturing strategy formulation processes, International Journal of Production Economics, 56-57, pp. 517-523.

Pooya, A., and Faezirad, M. (2017), A taxonomy of manufacturing strategies and production systems using self-organizing map, Journal of Industrial and Production Engineering, 34(4), pp. 300-311.

Porter, M.E. (1996), What is strategy?, Harvard Business Review, 74(6), pp. 61-78.
Porter, M.E. (1980), Competitive Strategy: Techniques for Analyzing Industries and Competitors, Free Press, New York, NY.

Prester, J., Podrug, N., and Tipuric, D., (2016), Manufacturing strategies in selected European countries, In: Raguz, I.V., Prodrug, N., Jelenc, L., Neostrategic Management: an international perspective on trends and challenges, Springer international publishing, pp. 173-188.

Robbins, S. P., and Coulter M., (2012), Management, $11^{\text {th }}$ Edition, Pearson, New Jersey.

Roos, G., and Kennedy, N. (2014), Global perspectives on achieving success in high and low cost operating environments, Business Science, Hershey PA.

Rosenzweig, E.D., Roth, A.V., and Dean, J.W., (2003), The influence of an integration strategy on competitive capabilities and business performance: an exploratory study of consumer products manufacturers, Journal of Operations Management, 21(4), pp. 437-456.

Sansone, C., Hilletofth, P., and Eriksson, D., (2017), Critical operations capabilities for competitive manufacturing: A systematic review, Industrial Management \& Data Systems, 117(5), pp. 801-837.

Sarmiento, R., Thurer, M., and Whelan, G., (2016), Rethinking Skinner's model: strategic trade-offs in products and services, Management Research Review, 39(10), pp. 1199-1213.

Seuring, S., and Müller, M. (2008), From a literature review to a conceptual framework for sustainable supply chain management, Journal of Cleaner Production, 16, pp. 16991710.

Skinner, W. (1969), Manufacturing - missing link in corporate strategy, Harvard Business Review, pp. 136-145.

Spring, M., Hughes, A., Mason, K. and McCaffrey, P. (2017), Creating the competitive edge: a new relationship between operations management and industrial policy, Journal of Operations Management, 49-51, pp. 6-19.

Szász, L., and Demeter, K. (2014), How do companies lose orders? A multi-country study of internal inconsistency in operations strategies, Operations Management Research, 7 (3-4), pp. 99 116

Voss, C.; Tsikriktsis and Frohlich, M., (2002), Case Research in operations management, International Journal of Operations and Production Management, 22(2), pp. 195-219.

Ward, P. T., Duray, R., Keong Leong, G. and Sum, C. C. (1995), Business environment, operations strategy, and performance: An empirical study of Singapore manufacturers, Journal of Operations Management, 13(2), pp. 99-115.

White, W., and Borchers, A., (2016), Motivation behind reshoring decisions in manufacturing, Operations and Supply Chain Management, 9(3), pp. 205-209.

Wiesmann, B., Snoei, J.R., Hilletofth, P., and Eriksson, D., (2017), Drivers and barriers to reshoring: A literature review on offshoring in reverse, European Business Review, 29(1), pp. $15-42$

Yin, R.K., (2014), Case study research: Design and methods, SAGE Publications, Thousand Oaks.

Yin, Y., Stecke, K. E., Swink, M., and Kaku, I. (2017), Lessons from seru production on manufacturing competitively in a high cost environment, Journal of Operations Management, 49-51, pp. 67-76.

Yusuf, Y. Y., and Adeleye, E. O. (2002), A comparative study of lean and agile manufacturing with a related survey of current practices in the UK, International Journal of Production Research, 40(17), pp. 4545-4562.

Zhang, X., Chen, R. Q., and Liu, P. Q., (2008), Exploring the congruence of functional strategies and customer integration strategy, Journal of Beijing Institute of Technology (English Edition), 17(SUPPL.), pp. 106-111. 
Zhao, X., Yeung, J. H. Y., and Zhou, Q. (2002), Competitive priorities of enterprises in mainland China, Total Quality Management, 13(3), pp. 285-300.

Cinzia Sansone (Lic. Phil.) is a PhD Student at Jönköping University in Sweden. She holds a Lic. Phil. in production systems (with specialization in production development and management) from Jönköping University (Sweden). Her research focuses on production and supply chain management with an emphasis on strategy.

Per Hilletofth is a Professor of Operations and Supply Chain Management at Jönköping University in Sweden and visiting Professor at University of Gävle in Sweden. His research focuses on demand-supply integration, operations strategy, supply chain relocation, product development, and decision support. He has published articles in international journals including Production Planning and Control, Expert Systems with Applications, Industrial Management and Data Systems, Journal of Business and Industrial Marketing, Innovation: Organization and Management, and European Business Review. He has editorial assignments in several international journals.

David Eriksson (PhD) is a researcher and Associate Professor at Jönköping University in Sweden. His research agenda consists of various research subjects including corporate social responsibility, methodology, new product development, supply chain management, and sustainability. He has editorial assignments in several international journals. 